\title{
Racial and Textual Translation Through Signifyin $(G)$ and Eshu: The Case of Juan Francisco Manzano's Personal Narrative Autobiography of A Slave
}

\author{
DR. JOSÉ ENDOENÇA MARTINS \\ UNIFACVEST, LAGES, SC; \\ EDUCOGITANS; NEAB/FURB; NEAB/UFPR
}

\begin{abstract}
To Paulina Gallardo, my mentor, who has been leading me through the ways of the Spanish Language, my most respectful thanks.
\end{abstract}

Cumplía yo ya seis años cuando, por ser demasiado vivo, más que todos, se me envió a la escuela en casa de mi madrina de bautismo, Trinidad de Zayas. Se me traía a las doce del día y por la tarde para que mi señora me viera, la cual se guardaba de salir hasta que yo viniese. De no ser así echava yo la casa abajo, llorando y gritando, y era preciso en este caso apelar a la soba, a lo que nadie se atrevía. Todos se guardaban de dármela, pues ni mis padres se hallaban autorizados a ello, y yo que lo sabía, si tal cosa me hacían, los acusaba. JUAN FRANCISCO MANZANO. Autobiografía de un Esclavo, 1996: 48.

When I was almost six, and more clever than the others, I was sent to school at the home of my baptismal godmother, Trinidad de Zayas. I was usually brought home at midday and in the evening so that the marchioness might see me, for she refrained from going out before I arrived. If she ever did leave, I raised such a fuss, crying and screaming, that I should have received a beating, but nobody dared do that. Everyone avoided it, for not even my parents were authorized to do so, and I, who knew it, tattled on whomever did such a thing to me. JUAN FRANCISCO MANZANO. Autobiography of a Slave, 1996: 49.

Já tinha eu seis anos quando, por ser esperto em demasía e mais do que todos, me enviaram à escola na casa de minha madrinha de batismo, Trinidad de Zayas. Às doze e também no meio da tarde, me traziam para que minha sinhá me visse. Ela evitava sair até que eu chegasse, pois, quando não vinha, eu derrubava a casa toda, chorando e gritando, e era preciso nesse caso apelar para a sova que ninguém se atrevia a me dar, porque nem meus pais se achavam autorizados para isso, e eu, sabendo desse fato, se me faziam tal coisa, os acusava. JUAN FRANCISCO MANZANO. A Autobiografia do Poeta-Escravo, 2015: 33.

\begin{abstract}
When black Brazilian poet Trindade describes himself in verses like "a black woman took me to the Church" and "another black woman took me to Macumba", he transfers his religious experience from the divine to the human. Similar to Trindade's poetic two-ness, Eshu also celebrates his representation as two-headed orisha. The duality of Trindade and the dualism of Eshu are intermingled via Gates's (1988) Signifyin(g) and its support to dialogue between three literary black texts. From this dialogical perspective, this study aims at replicating the "call and response" process, by means of which African-Cuban writer Juan Francisco Manzano's (1996) Autobiografia de un Esclavo and its English and Brazilian-Portuguese versions Autobiography of a Slave and A Autobiografia do Poeta-Escravo establish translational conversation through interraciality and intertextuality. Racially, I analyze entanglement and separation between Spanish Cuba and black Cuba; linguistically, I discuss disentanglement and harmony between Spanish, English and Brazilian-Portuguese languages. Interracial and interlinguistic analysis focuses on the discussion of two translational axes, mingling the translation of Manzano himself and of his narrative. The emphasis on interraciality and intertextuality helps us see translation as conversation between the two racialized worlds involved and the three specific literary products. The study of Manzano's life highlighting his proximity to Spanishness and distancing from Blackness is encapsulated within Negriceness; the analysis of rendition of the autobiographical text emphasizes similarities between the source and target versions of the narrative endorsed by Paralatio.
\end{abstract}

Keywords: Signifyin(g). Eshu. Translation. Whiteness. Blackness. Negriceness. Paralatio.

\section{Opening Comments}

The three epigraphs - one in Spanish, another in English and the third in Brazilian Portuguese - introduce the theme of black identity mobility within the 19th Century Cuban slavery experience, as it is narrated within slave Juan Francisco Manzano's (1996) Autobiography of a Slave. 
Within these three autobiographical quotes, Manzano describes an autobiographical event of his life, in which, at the age of six, he portrays himself as an adopted member of the family of his white mistress Doña Beatriz de Justiz, Marchioness de Santa Ana and wife of Don Juan Manzano.

In addition, in the same personal happening, Manzano reports that he is a baptized slave boy who also has access to initial education in the house of his baptismal godmother Trinidad de Zayas. This threefold stage of Manzano's interracial identity mobility - a white family, a white religion, a white education - within the Spanish-Cuban slavery reality determines the slave narrator's adherence to the modality of Western values dominant in Cuban society of the time. The personal narrative of the slave boy demonstrates that Manzano feels so comfortable under Christian and educated Doña Beatriz de Justiz's total protection, that he dares to behave strangely. For example, he reports that, on one specific occasion, when he does not see the marchioness at home after coming from the godmother's learning hours he causes a terrible mess. "I was usually brought home at midday and in the evening so that the marchioness might see me, for she refrained from going out before I arrived. If she ever did leave, I raised such a fuss, crying and screaming" (MANZANO 1996: 49), he reports. Manzano behaves so because he feels so fully protected in that house, knowing that no one, not even his parents, except the marchioness, would dare to punish him for his bad behavior. Such a move from a slave family into the white cultural environment of the slaveholders Manzanos' house clearly anticipates six years-old slave boy's future trajectory from memorization to writing/reading, from décimas to sonnet, and, finally, from slavery to freedom. Manzano's moves antedate a glimpse of his future poetic artistry under the mentoring of Cuban intellectual leader Domingo Del Monte, in Havana. Such an interracial and interclass dislocation allows the slave to manage racial gains, losses and exchanges in his contact with other slaves in conditions similar to his, and with free people.

Having Manzano's identity mobility - quest for learning, poetry, freedom - as its practical and theoretical scopes, this study encompasses two modalities of translation: one marked by the slave's interracial dislocation and another visible in his narrative's intertextual displacement. I evaluate Manzano's interracial translation as he moves from the Blackness of his slave family to the Whiteness of Marchioness de Santa Ana's house; on the other, I accompany the intertextual rendition of the slave boy's autobiography, as Schulman's (1996) transfers it from Spanish to English and Castro (2015) makes it move from Spanish to Brazilian-Portuguese. Thus, two translational processes occur: (1) slave Manzano portrays his dislocation between two distinct races, a movement which allows him to build racial identity through a dynamic modality of cultural mutability; (2) the translators - Schulman and Castro depict Manzano's autobiography going through a process of intertextual migration between distinct languages. Migration enables Manzano's narrative to construct textual identity by endorsing linguistic changeability. As a result, both Manzano and his autobiography operate within the construction of specific identity while they trade race and language, or humanity and text. There occur, then, the presence of two distinct but complementary dislocations, one interracial and one intertextual. As for race, the Afro-Cuban Juan Francisco Manzano is adopted by the family of Doña Beatriz de Justiz, Marchioness de Santa Ana and wife of Don Juan Manzano. This an autobiographical fact that conditions his life as a slave, helping him become a free man and a poet, but leading him to neglect the original values of his black family as well. Regarding language, Autobiography of a Slave moves between the three languages involved in the process of translation, which portrays how the source text of Spanish differentiate itself from the target versions, the English and the Brazilian-Portuguese. Here, the reader witnesses how both racial and lingual migration highlights the specificity of both Manzano's life and the dynamics of the autobiographical tale.

In order to highlight the perception that any act of migration imposes on the dislocating selfness and otherness a significant amount of losses, gains and exchanges - both racial and textual, respectively - it is plausibly inferable that the act of migrating articulates with the process of translating, due to interchangeable elements within the notion of translation. As our perception is that migration and translation tend to harmonize in a triangulation that also involves tradition, we postulate that the discussion of black diasporic literature may take advantage of the close connection between the concept of Signifyin $(g)$ and the conceptual energies of Eshu. Since the years of the trade of Africans to the Americas, both Signifyin $(g)$ and Eshu have been associated with the black identity triangulation made up of tradition, migration and translation. Thus, the encounter involving the two elements - the literary linking to Signifyin $(g)$, the racial connecting to the orisha - is based on the eventuality of a dialogue between two distinct phenomena leading to generating a third situation. In the literary sphere of Signifyin $(g)$, the conversation between two black texts contributes to the birth of a third black work. Similarly, within the racial sphere of Eshu, the dialogue between the gods and the persons leads to the inevitability of a third religious orientation. In both cases, the third alternative will always generate more possibilities within life and meaning creation. Through $\operatorname{Signifyin}(g)$, the conversational encounter of two black texts tends to generate a third narrative. Under the auspices of Eshu, the alliance between the deities and the human beings will bring about a third auspicious moment of communication. In view of the triangulation derived from both Signifyin $(g)$ and the orisha, it can be demonstrated that, according to the philosophical-religious experience encompassed within Yoruba philosophy, "two, it becomes three". 
In other words, the union of the two elements under negotiation (blackness and whiteness; Spanish and English/Brazilian texts) will lead to a tertius that asks to be born. Activated by the triangulation, it can be said, then, that the black world, both within the literary realm and the racial (religious) arena, articulates a continuing movement leading to identity mobility.

Thus, the thesis that encapsulates the triangulating process of translation under the influence of the statement "two, it becomes three" can be read in these terms: "a tradition moves towards its translation through its migration". Here, the terms tradition, migration and translation arise from the racial relationships they are capable to establish between Cuban Blackness and Cuban Whiteness. Therefore, what emerges from the thesis is that translation operates within the encounter of tradition and migration. Then, tradition as the original entity, when touched by migration, leaves its original stage in order to reach the future stage of translation. Thus, black translation - the literary one through Signifyin $(g)$; the racial one through Eshu - is always what occurs due to the dynamic and productive encounter of a black tradition with black migration. As a result, tradition, migration and translation are the basic terms that make up the phenomenon of both racial [with Eshu] and textual [with $\operatorname{Signifyin}(g)$ ] $\operatorname{translation.}$

Our analysis in this essay, involving Manzano and his personal narrative suggests that black literature is the locus where the statement "two, it becomes three" works concretely, based on the combination of a tradition, a migration and a translation. Previous intercontinental (Africa, Americas, Caribbean, Europe) and interlinguistic (German, English, French, Portuguese, Spanish) studies involving black texts and black subjects, developed by this researcher, already demonstrate the plausibility of this methodological approach to literary analysis and theory of translation. (see MARTINS, 2003; 2013) Within the analytical approach that will be carried out from now on, Manzano's (1996) Autobiografía de un Esclavo along with both Schulman's (1996) translation of the original into English as Autobiography of a Slave and Castro's (2015) rendition of the source version into Brazilian-Portuguese as Autobiografia do Poeta-Escravo offer the appropriate textual and racial elements that make possible to ascertain the scope of the thesis, which not only problematizes the translational links between tradition, migration and translation, but also enhances the identity characteristics of mobility under the auspices of the expression " $t w o$, it becomes three".

\section{Juan Francisco Manzano's Literary Activism and Libertarian Protagonism in his Autobiography of a Slave [Autobiografía de un Esclavo]}

With the analysis of African-Cuban slave Manzano's (1996) Autobiography of a Slave [Autobiografía de un Esclavo], I wish to analyze the two translating modalities - racial and textual - and demonstrate how both Manzano and his narrative go through the process of migration. Racially, the narrator translates himself as he migrates from the black tradition of his slave family to the white house of his masters. Linguistically, his is translated as it moves from the Spanish language to both English and Brazilian-Portuguese tongues. Within this double modality of translational dislocation, Manzano encompasses racial translation while his text embodies textual rendition. In the analysis, emphasis lies on the ways the slave's autobiography deals with political and literary aspects involving poetry writing and freedom. As for politics, there excels his struggle to be free; regarding literature, there stands out his fight for writing learning to be a poet. A relevant event in this regard is his sonnet My Thirty Years [Mis Treinta Años], which joins together poetic quality and freedom fighting. These 14 verses is praised by Cuban abolitionist and reformist Domingo Del Monte, the mentor who also asks him to write the autobiography. In his analysis of the poem, African-American literary critic Aching (2015) asserts that

The poem begins as a moment of self-reflection, mingled with astonishment, as the poet takes stock of the span of time that has transpired since his infancy. In attempting to fathom his life experiences over this period, he intimates that it is with fear and trembling, rather than with due attention, that he hails the hardships that have characterized his existence. (ACHING 2015: 53)

The second triplet of the sonnet coincides with Manzano's "fear and trembling" pointed out by Aching. It shows how the poetic voice of the slave loses hope to conquer his freedom in the near future. He closes the denunciation of physical, spiritual and psychological sufferings he is lead to endure with these verses: "but "tis nothing the past or the pains,/Hitherto I have struggled to bear,/When I think, oh, my God! On the chains,/That I know I'm yet destined to wear." (MANZANO, 2015: 208) "The pains" and the "struggles endured", two expressions the poet uses to describe his misfortune in slavery, anticipate the type of tragic and painful existence that Manzano will portray in Autobiography of a Slave.

As we will see in his personal narrative, along with the denunciation of slavery and the condemnation of its rulers and perpetrators, it is the poem that motivates, sustains and supports Manzano's inner strength, as he uses his poetic ability to appease and endure suffering. Aching (2015) argues in favor of Manzano's personal inclination towards the verses attesting that "poetry was the medium with which Manzano felt most comfortable. As a child, he had displayed a gift of gab, a facility for rhyming, and a prodigious memory for reciting poetry, sermons, and speeches from Masses and plays that he attended as his mistress's page." (ACHING 2015: 04) 
In this regard, one can read in the autobiography that, at the age of 10, Manzano's "prodigious memory" becomes an advantage as he is able to memorize everything he hears: the sermons of religious preachers, such as those of Fray Luis de Granada, the prayers, the catechism, the plays and long parts of the operas. Over time, he begins to compose his own décimas orally, with great success, as he himself reports that "by the time I was twelve years old, I had already composed several décimas by memory."(MANZANO 1996: 57)

Later, he mentions his method of composition, saying that "I did not write the verses down since I did not know how, but I possessed a mental notebook of verses and improvised anything." (MANZANO 1996: 63)

An additional aspect of Manzano's poetic inclination since childhood is his struggle for writing learning. This long, exhaustive and energy-consuming learning process goes from the memorization of other persons' verses, décimas, sermons and texts to the copying of them with the help from Serafina who writes down the passages he speaks to her. Due to its limiting aspects, Manzano decides to learn how to write. Such a decision is put into practice during the years he spends with Señor Don Nicolás. There, Manzano takes advantage of the living conditions his masters dispenses to him, favoring intellectual and mental activities. He reports that Don Nicolás "loved me, not as a slave, but as a son" (MANZANO 1996: 103), buying him new and better clothes. "I was well-treated, better-dressed, and more loved. I had a coat that my new master had ordered made for me and had many reales" (MANZANO 1996: 103), he rejoices. Don Nicolás's daily immersion into studies, reading and writing, also fortifies Manzano's motivation towards writing learning. He reports about his success in writing, after a month of intense night-working practice, in secrecy:

Very happy with my successful experiment, I spent from five to ten o'clock practicing my hand at making small letters. Even during the day, when I had time, I also practiced. I would station myself at the foot of a painting whose title was in capital letters. With many strokes I was able to imitate the most beautiful letters. I succeeded then in making them look more like engravings than handwriting. (MANZANO 1996: 105)

Manzano's artistic success attracts both apprehension and recognition. When Don Nicolás discovers about Manzano's self-learning routine, he scolds the slave, reminding him that writing "did not correspond to my class." (MANZANO 1992: 104) However, Manzano advances in his objectives, finding a literary model in the poet Juan Bautista Arriaga y Supervilla, "whose poetry I had memorized, [he] was my guide." (MANZANO 1996: 127) He also gains support and recognition of Don Coronado, a friend who "confirmed that most [aspiring poet] had begun the same way." (MANZANO 1996: 105) As he now possesses poetic independence he feels stronger to plan his running away from bondage to Havana. As he is allowed to doing certain jobs and practicing some lucrative activities he manages to earn some money. He reports that "if I were free today I would not lack anything to eat, so to speak, but only possessions." (MANZANO 1996: 126) Later, a slave advises him to run away, telling also that Havana is 12 leagues from the house. Manzano reports about his conversation with the friend:

The next day, a Sunday, when everyone was at mass, a free servant of the house called me aside and said, "Look, young man, aren't you ashamed of being so mistreated? Any African is treated better than you. A mulatto youth like you, with as many skills as you have, will find someone to buy him in a second". (...) He pointed out to me the road that went from there to Havana, telling me to take advantage of the first opportunity and to not be stupid. (MANZANO 1996: 130)

Many other slaves also encourage him to escape from slavery. Finally, when is leaving to Havana he is surprised by a voice that wishes him good luck. He believes he is acting in secrecy, but his movements are scrutinized by others, from the darkness of their windows. Unfortunately, regarding what happens to Manzano from the moment he runs away from slavery, the reader will never know from the narrator's own writing. This is because, according to Richard R. Madden's report, the translator the first part into English, it "fell into the hands of persons connected with his former master, and I fear it is not likely to be restored to the person to whom I am indebted for the first portion of the manuscript." (SCHULMAN 1996, 28)

\section{Gates's Signifyin(g) as a dialogue between black texts}

Previous observations cover the translational processes which Manzano's (1996) Autobiography of a Slave goes through, as it depicts the Cuban slave's dramatic struggle for poetic expression and freedom during his 30 years of devastating bondage. Furthermore, my previous thoughts place Manzano and autobiographical text in the context of both interracial and intertextual conversation by addressing two important aspects of his life: on the one hand, his move from his black family to the white families of slaveholders; on the other hand, the translational trajectory his autobiography makes as it journeys from Spanish to English to Brazilian-Portuguese. During his captivity period in the houses of Cuban slaveholders, Manzano encompasses interconnections of the black individual's objective with the black group's expectations. In the ways he joins the personal and the collective together, the slave portrays himself, consciously or unconsciously, a representative of his community. As his group also fights for freedom, it supports Manzano's efforts to run away from slavery. 
The community's support of the individual's struggle for freedom is verbalized by other slaves, at least, two times. It occurs when a slave shows Manzano the road to Havana, the city to which he wishes to run away. "He pointed out to me the road that went from there to Havana, telling me to take advantage of the first opportunity and to not be stupid" (MANZANO 1996: 131), Manzano reports. Later, this happens again when the community of slaves wishes him success. "God be with you. Hurry long” (MANZANO 1996: 135), they say.

Such a political reciprocal commitment of the oppressed individual and the dispossessed group, both united in the same struggle for freedom, mirrors the theoretical perception Deleuze \& Guattari (1986) bring to the close relationships between the individual and the communal. The thinkers discuss such a view in the oeuvre Minor Literature, arguing that everything in minor literature "is political" and "its cramped space forces each individual intrigue to connect immediately to politics". As a result, "the individual concern thus becomes all the more necessary, essential, magnified, because a whole other story is vibrating within it." (DELEUZE \& GUATTARI 1986: 17) In addition, they propose that "everything takes on a collective value" in minor literature, which highlights the idea that "what each author says individually already constitutes a common action, and what he or she says or does is necessarily political, even if the others aren't in agreement." (DELEUZE \& GUATTARI 1986: 17) I incline myself to take Manzano and his community as an exemplification of what the French scholars defend. By the same token, Grewal (1998) finds in Morrison's novels similar personal-political relationships and individual-communal connections. Grewal suggests that "Morrison's novels aim to redistribute the pressure of accountability from the axis of the individual to that of the collective. Her art draws its imperatives from personal and collective histories", and so doing, her writing fuses "the liberation narrative of black history itself" with the interrogation of "national identity and social memory", besides linking "a people dispersed by difference to a common past." (GREWAL 1998: 11)

Gates (1988) amplifies the scope of both mine and Grewal's (1998) exemplification regarding the imbrications of the individual and the communal. His concept of $\operatorname{Signifyin}(\mathrm{g})$ fits in here due to the intertextual and dialogical aspects present in black literature, which is the central topic within his seminal work The Signifying) Monkey: A Theory of African American Literary Criticism. In it, he advocates dialogical qualities of Signifyin( $g$ ) by arguing that the black American literary production is nurtured by its authors' ability to establish conversational aspects between previous works and subsequent texts, thus activating an intertextual talk that seems to function by means of four modes of dialogue: imitation, repetition, revision and difference. In his essay, conversational quality of $\operatorname{Signifyin}(g)$ is portrayed as the black tradition of double-voice - a voice that calls, another that responds - in which the novel text (the responding calling) speaks with the previous text (the calling voice). The Orisha Eshu, with his two mouths - deity's sculptures show one mouth looking back or searching for the past (the previous work) and the other looking forward, scanning the present (the future text) - encompasses the double expression of black literature of the "call and response" motto. Gates joins the two-ness of both Signifyin $(g)$ and Eshu together, writing that "the black tradition is double-voiced. The trope of the Talking Book, of double-voiced texts that talk to other texts, is the unifying metaphor within [black literary tradition]. Signifyin $(g)$ is the figure of the double-voiced, epitomized by Esu's depictions in sculpture as possessing two mouths." (GATES 1988: XXV)

If one takes such an intertextual dialogue within intrarracial literary tradition to the realm of interracial artistic environment, motivated by the conversational orientation of Signifyin $(g)$ and Eshu, one may argue in favor of the postcolonial aspects of black literature. As the Postcolonial joins the Colonial and the Decolonial together, colonization of the black author associates him with literary Whiteness. In this sense, Gates (1988) argues that "black writers, like critics of black literature, learn to write by reading literature, especially the canonical texts of the Western traditions: consequently, black texts resemble other, Western texts." (GATES 1988: xxii) By the same token, Vergès (2005) validates this extraordinary interpenetration between white literature and black literary production, reorganizing it as an interdependence between the center and the periphery, which implies that "the interactions between the metropolis and the colony", highlighting that "the colony is not the space outside the metropolis." (VERGÈS, 2005: 75) Between Gates's gaze of the interconnections between Whiteness and Blackness in black literature, and Vergès's examination of the imbrications between the metropolis and the colony, there exists the flow of time participating and contributing to our comprehension of postcolonialism.

Over time, cultural development, literary maturity, or artistic success and a sense of independence have brought contemporary black writers into an opposite position: they change their previous literary perspectives and abandon white influence in order to develop a genuine black model, thus exercising decolonization. This change in the orientation within black writing - it moves from Whiteness to Blackness; from colonization to decolonization does not make colonization disappear, neither from gaze, nor from texts. As matter of fact, such an ambivalent situation makes white colonizing forces concomitant with black decolonizing energies. A vital consequence of such concomitance within Negro literary culture is that colonization weakens, becomes porous and makes room to the new decolonizing perspective. Gates (1988) recognizes black adoption of this new modality of art, saying that "free of the white person's gaze, black people created their own unique vernacular structures and relished in the double play that these forms bore to white forms. 
Repetition and revision are fundamental to black artistic forms, from painting and sculpture to music and language use." (GATES 1988: xxiv) In other words, Gates's statement asserts that repetition and revision within black and white artistic forms give black authors their own peculiarity, as they recover Eshu's double expression through Signifyin $(g)$. Looking at black narratives as fictions whose influence comes from "black and white novels", Gates goes on to say that "one can readily agree with Susan Willis that black texts are "mulattoes" (or "mulattas"), with a two-toned heritage" (GATES 1988: xxiii), composed by black and white characteristics.

Mulatto novels are double-voiced literary events that highlight Eshu's double vocality in black literature. With the intervention of the orisha, this mulatto-ness joins together Whiteness and Blackness, colonization and decolonization, metropolis and colony, center and periphery, source and target text. As a result, separation, rivalry, or conflict between these dualities is mitigated, and mutual contribution prevails. Therefore plurality replaces polarity, connected components substitute separated parts. The mingling of antagonistic elements is Eshu's responsibility, due to Yoruba divinity's inclusion of these three elements - the past, the present and the "unborn", or the future - which coexist simultaneously without philosophical conflict. For Gates, Eshu is the force eliminating contradiction because the orisha "represents these stages and makes their simultaneous existence possible 'without any contradiction', precisely because he is the principle of discourse both as messenger and as the god of communication", represented by "the concept central of the Ogboni secret society that "two, it becomes three'." (GATES 1988: 37)

One can deduce, then, that it is orisha's conversational motto "two, it becomes three", which implies fusion, not split, that makes colonization, decolonization and postcolonization conflate. Such conflation implies that postcolonial experience derives from the relationships of colonization and decolonization, metropolis and colony, Center and Periphery. From Gates's (1988) view, black postcoloniality evolves from the contacts between literary blackness and whiteness. Vergès (2005) recognizes postcolonial flow as an important aspect for the eradication of binarism. She writes that the idea of flow "breaks with the idea of a static, fixed thought, which would only be worked from outside. (...) What the notion of flux seeks to emphasize is the trans-national, trans-continental aspect, [leading to] Transculturation, métissage, hybridization, creolization (...) [which] describe the cultural processes and practices of borrowing, of bricolage." (VERGÈS, 2005: 85-86)

Considering the notion of flow authorizing the influence of Eshu and Signifyin $(g)$ in the dialogical energy and conversational force involving black texts, I raise two questions: (1) can the racial connections between Eshu and $\operatorname{Signifyin}(g)$, as they have been discussed so far, be applicable to black literature other than its African-American specificity? (2) can Eshu's encounter with Signifyin $(g)$ be proper for a theory of literary translation? In this article, both questions are answered positively. The first positive response is provided by Gruesser (2007), as he states that "signifyin $(\mathrm{g})$ is especially useful in analyzing how texts, within specific genres, respond to other texts." (GRUESSER 2007: 57) So, he reiterates Gates's (1988) point of view already dealt with previously in this analysis. Gruesser also asserts that "the theory can be effectively applied to texts that are outside of the African American literary tradition" (GRUESSER 2007: 57), where the theory is originated. So, he amplifies Gate's scope for the concept. As a result, Gruesser enlarges his understanding of Gates's concept by emphasizing that Signifyin(g) is a textual, rhetorical, metaphorical and dialogical phenomenon within black literature, in which two texts establish connections through repeating or reversing in the second novel aspects of the first work. The positive answer to the second question advocating Signifyin $(g)$ as a theory of translation will be addressed in the following section of this study, in which I discuss two specific modes of translation, racial and textual.

\section{Linguistic and Racial Translation: Interconnections between Negriceness and Paralatio.}

This section aims at establishing the basic principles of a personal proposal for the field of translation theory. I intend to argue that literary Signifyin $(g)$ can also function as translation theory. I specifically postulate the idea that both racial and linguistic translation may take advantage of Gates (1988) Signifyin $(g)$, as the concept acts on the assumption that dialogical intertextuality energize, theoretically, literature and translation as well. As the concept is originally conceived by Gates as a conversational play involving two texts, in a "call-and-response" process, my personal theoretical design for $\operatorname{Signifyin}(g)$ as a theory of translation appears to be feasible. I justify its transposition from one theoretical milieu to another because by proposing that, within the field of translation, Signifyin $(g)$ will ally itself to the idea that people and texts go through a process of translation due to cultural impositions. In addition, I suggest that in order to become translated subjects and objects, people and texts must, respectively, migrate from their original human or linguistic tradition to another human or linguistic heritage. In other words, I insist that, in order for translation to become an effective migrating phenomenon it must make people and texts go through a process of self-transformation while dislocating from one racial or linguistic origin to a distinct racial or textual tradition.

I retake here my thesis, already introduced elsewhere in the article, that "a (racial, linguistic) tradition becomes a (racial, linguistic) translation through a (racial, linguistic) migration." (MARTINS, 2013: 56) 
As a result of historical facts regarding the experience of the black diaspora, in particular, black slavery, racial migration involves a back-and-forth exchange between black and western traditions that have turned the world into an appropriate environment for the intermingling and creolization of distinct cultures. Therefore, in this environment of cross-cultural exchanges, the human and racial dimension of my thesis receives a more consistently elaborated articulation, according to which, "racial traditions migrate with people who move and, as they move from one tradition to another, they go through translation. As a fluid concept, racial translation goes beyond the isolating dichotomy of the two traditions [and] welcomes reciprocity, exchange, mixture and creolization." (MARTINS 2013: 56)

The migration between traditions does not limit itself to the racial field, or people of African descent who migrate, but expands itself to linguistic and textual phenomena like books. I must admit that linguistic migration resembles racial migration as it performs a book's back-and-forth movement between its departure from a linguistic tradition and its arrival in another linguistic heritage. Here, I suggest that translation, from the linguistic or textual perspective, is based on "the dispersion of a black text through the dialogue between writing and rewriting", in which "dichotomy between the source and target traditions is overcome by the hybridization of the two texts", turning translation into "a process of linguistic intertextual creolization." (MARTINS, 2013: 58)

Both racial and textual translation has its concepts. Its racial perspective includes three notions, Negriceness, Negritude and Negriticeness. Its textual orientation moves between the three other names, Paralatio, Similatio and Translatio. Both racial and textual translation works in a triple orientation, in association with three universally established theories, Domestication, Foreignization and Hybridization. The first trio favoring a combinatory analysis of both race and language includes Negriceness, Paralatio and Domestication, whose analytical aims is to demonstrate how the hegemonic forces of the incoming traditions disenfranchise the outgoing heritage. The second trio groups Negritude, Similatio and Foreignization together, but reverses the direction of racial and textual displacement of the previous one in order to privilege the translational specificities and energies of the outgoing heritage in detriment to the incoming tradition. Finally, the third trio involves Negriticeness, Translatio and Hybridization, whose analytical proposal seeks to debilitate the effects of the polarity reinforcing the asymmetric perspectives of the two previous trios by replacing dichotomy for a more egalitarian combination of the two traditions involved in the racial and textual translational process.

For the practical application of both interracial and intertextual analysis of Manzano's (1996) Autobiography of a Slave, the conceptual trio that interests me here groups Negriceness, Paralatio and Domestication together. The choice of this specific triangulation of analysis is explained from both the racial and textual point of view. Racially, the choice is justified by the fact that, due to the long exposition to the white cultural values, strongly reigning within the slaveholders' domains, Manzano ends up becoming a Black assimilationist of this westernized cultural atmosphere. Manzano's relationships with, loyalty to and assimilation of the Whiteness represented by this SpanishCuban masters are visible in his narrative, as he writes: "I grew alongside my mistress without leaving her side except to sleep, for she never even traveled to the countryside without taking me along in the coach." (MANZANO 1996: 46) Linguistically, the interconnections of Paralatio with Domestication of Manzano's Autobiography of a Slave are carried out as the narrative goes through a process of dislocation from Spanish, the source language, to two distinct target languages English and Brazilian-Portuguese. This movement between the outgoing tongue and the two incoming languages concentrates on linguistic differences and, thus, leads the target reader to believe that he/she does not read a translation.

Through the aspects joining Negriceness, Paralatio and Domestication together, I manage to conduct, through translation analysis, two identity phenomena. On the one hand, Negriceness allows to measure Manzano's adherence to the cultural whiteness of the Cuban slave owners, therefore developing assimilationist identity; on the other hand, Paralatio helps evaluate the disenfranchisement of Spanish, the source language, in favor of the empowerment of both English and Brazilian-Portuguese, the two target tongues. As a result, racial assimilation and textual Domestication are present in the way both Negriceness and Paralatio work. Through Negriceness, we assess the extent of Manzano's Domestication, that is, his assimilation of, submission to, or voluntary adhesion to, the hegemonic cultural values of Cuban whites. With Paralatio, we qualify the Domestication of Manzano's original narrative by the linguistic and cultural power of its translation over both English and Brazilian-Portuguese. What seems to be limiting within the analytical reach here is the fact that the trio highlights exclusively the case of a unidirectional migration - the one from source tradition to target heritage - thus preventing the back-and-forth movement required by a true translation from occurring.

The analysis in the following paragraphs combines Negriceness and Paralatio. The imbrications of racial and textual aspects reflect Manzano's adhesion to the Cuban Whiteness together with Spanish language's disenfranchisement under the linguistic peculiarities of English and Brazilian-Portuguese, thus clearly characterizing translational Domestication of a black person and a black text. Extracted from Manzano's autobiography, the excerpt under analysis is below: 


\section{Negriceness}

Como carecía de escritura para estudiar las cosas que yo componía hablaba solo, haciendo gestos y afecciones según la naturaleza de la composición. (...) Entonces determiné darme algo más útil, que fue el aprender a escribir. (...) Sin embargo, compré mi tajaplumas, plumas, y papel my fino y con algún pedazo de papel de los que mi señor botaba, escrito de su letra, lo metía entre llana y llana con el fin de acostumbrar el pulso a formar letras. Iba siguiendo la forma de lo que tenía debajo. Con esta invención antes de un mes ya hacía renglones logrando la forma de letra de mi señor. Por eso hay cierta identidad entre su letra y la mía. (Manzano, Autobiografía de un Esclavo 1996: 64-102).

\section{Paralatio (En)}

Since I lacked writing skills, in order to study what I was composing I used to talk out loud to myself, affecting gestures and emotions according to the nature of the composition. (...) It was then that I decided to dedicate myself to something more useful, learning to write. (...) I, nevertheless, bought myself a penknife, quills, and very fine paper, which I placed over a discarded sheet written in my master's hand in order to accustom myself to the feel of fashioning letters. I worked along tracing the shapes on the paper below. With this method, in less than a month I could already write lines that imitated my master's handwriting. For that reason there are certain similarities between his penmanship and mine. (Manzano trad. Evelyn P. Garfield 1996: 63-105)

\section{Paralatio (Por)}

Para praticar minhas coisas, que eu compunha de memória por carecer de escritura, eu falava sozinho, fazendo gestos e expressões segundo a natureza da composição. (...) Então, decidi dar-me outro uso mais útil, que foi o de aprender a escrever. (...) No obstante, comprei apara-penas, penas, papel muito fino, e pegava algum pedaço de papel escrito dos que meu senhor jogava fora, com sua letra, e os colocava entre folha e folha, a fim de acostumar o pulso a desenhar letras e ia copiando a forma da letra que ficava embaixo. Com essa invenção, antes de um mês já fazia linhas inteiras, alcançando a forma da letra do meu senhor, motivo pelo qual há certa semelhança entre sua letra e a minha. (Manzano, trad. Alex Castro 2015: 42-67)

In this excerpt, slave Manzano's Negriceness, or his quest for white cultural values as, for instance, effective literacy, takes a very practical path regarding his own project of poetic and literary aspirations. Living with his master Don Nicolás, working for him as the organizer of his master's daily routine and personal affairs, such as clothes, food, books and studies, Manzano is aware that, if he wishes to be a poet and a writer within this white cultural millieu, he cannot go on without eliminating one of his more limiting deficiency, his inability to write in Spanish, the slaveholder's language. In his search and fight for self-realization and self-affirmation in the artistic white world of Cuban slavery, the enslaved Manzano reflects that the possession of writing for literary purposes represents a robust step towards his liberation, which he cannot postpone. He has already learned to compose his own décimas and other verses through the strenuous process of memorization; he has already memorized the oral and written versions of other poets' composition, with and without the help from Serafina; he nas already taught himself how to say these verses to his public made up of black slaves and freedmen, young and adult captives.

However, he feels that the lack of writing ability has become such a huge impediment to his literary ambition and future freedom that he decides to find an immediate solution for the problem. As his condition as an enslaved person prevents him from going to school in order to acquire the necessary writing ability, formally and institutionally, Manzano decides to develop his own methodology to achieve this dream to master writing. Living in the house of a highly learned and educated man like Don Nicolás, who is surrounded by books and written texts of his own manufacture and of others', Manzano senses where to find the proper ingredients which will lead him to develop his own writing skills. From the literary resources that he finds in his master's home office, Manzano devises a very intelligent and effective strategy: he decides to teach himself how to develop and acquire white literacy, that is, to master the Cuban Spanish used by plantation owners, by imitating and replicating the handwriting of slaveholder Don Nicholás, his master. It is a long and sophisticated process of calligraphic imitation, which includes the purchase of penknives, feathers, and very fine and transparent paper, the application of this transparent paper over the text written by the slaveholder, and the careful copying of his letters, words, sentences and texts. For a whole month, Manzano follows this intricate and exhaustive process of copying, imitating, repeating, replicating and revising Don Nicolás's handwriting, until he manages to make his own handwriting similar to that of the master. Manzano's painful but innovative modality of self-learning results in the acquisition of a skill as if it were seized in the learning environment of formal and institutionalized education in a school. Finally, when Manzano evaluate his works he acknowledges the success of his personal enterprise and congratulates himself, saying "for that reason there are certain similarities between his penmanship and mine." (MANZANO 1996:105) Here, indeed, the words of Du Bois ([1903], 1984) echo, and give voice to, Manzano's personal efforts toward self-learning writing ability. 
The African-American thinker claims that a black man, like the Cuban slave, "felt the weight of his ignorance - not simply of letters, but of life, of business, of the humanities -", and went on to create his own path to selfempowerment because "he began to have a dim feeling that, to attain his place in the world [white], he must be himself and not another." (DU BOIS, 1984: 368)

As shown in the previous paragraph, Manzano's Negriceness - the concept for his strategic assimilationist identity - deals with a very delicate and, at the same time, very productive moment in the life of the Cuban slave, during which he manages to self-learn white writing, symbolized in the handwriting of his master Don Nicolás. From now on, one enters the real of Paralatio, the concept implying the displacement of Manzano's Autobiografía de un Esclavo from Spanish to English and Brazilian Portuguese. Such an intertextual movement encompasses an example of the domestication of the source text under the linguistic peculiarities of the two target languages.

Paralatic domestication, transparency or fluency implies submission of the source text - differentiation from - to the linguistic properties of the target text. By arguing that intertextual difference within source and target languages is the task of both translation and translators, Chesterman (1997) asserts that "a translator is not someone whose task is to conserve something but to propagate something, to spread and develop it: translators are agents of change. Translators, in fact, make a difference." (CHESTERMAN 1997: 02) Through Paralatio, one analyzes here how both Schulman and Castro work in order to distinguish target languages B and C from source language A, from three specific linguistic aspects, Semantics, Syntax, Pragmatics. Paralatio, that is, the deliberate change or linguistic alteration of the source language in order to make the original text more palatable for a larger target readership, begins here with lexical synonymy. Regarding paralatic lexicality, semantic differences between Spanish, English and Brazilian substantives show that the translators Schulman and Castro make the source nounss [afecciones], [tajaplumas], [renglones] and [identidad] distinct from corresponding English versions [emotions], [penknife], [lines] and [similarities] and from Brazilian counterparts [expressões], [apara-penas], [linhas] and [semelhança].

In his paralatic proposal, English Schulman also treats the Spanish word [letra] in three different ways, as [hand], [handwriting], and [penmanship], while Brazilian Castro decides to avoid its lexical distinction. In the field of lexical correspondence between words and locutions, Schulman insists on the differences between the two languages, making the noun [escritura] arrive in English as the locution [writing skills], and [solo] as [out loud to myself]. Castro, on the other hand, transfers the adverb [solo] to Brazilian Portuguese as [sozinho]. Locutional Paralatio also illuminates translational distinction between the three languages. For instance, Schulman transfers to English the Spanish expression [antes de un mes] as [in less than a month], while making the expression [por eso] arrive in English as [for that reason]. Here, Castro associates it with [motivo pelo qual], in Brazilian, thus contributing to establish differences between the languages involved. In addition to the numerous lexical and locutional differentiations between involving the languages in the translation process, Schulman Garfield and Castro manage to create distinct translational options by means of syntactic decision. Initially, dealing with the source sentence [determiné darme algo más útil] Schulman transforms it in the English sentence [I decided to dedicate myself to something more useful], and Castro makes it [decidi dar-me outro uso mais útil] in Brazilian.

As a result, Castro differentiates [decidi] from [determiné] and Schulman distinguishes [I decided to de dedicate myself] from [determiné darme]. Syntactic transformation occurs again when both Schulman and Castro transfers the source sentence [con algún pedazo de papel de los que mi señor botaba] to their languages as [a discarded sheet written in my master's hand] and [algum pedaço de papel escrito dos que meu senhor jogava fora], respectively. A final syntactic occurrence indicates translational decisions that distance source item [logrando la forma de letra de mi señor] from English [imitated my master's handwriting] and Brazilian [alcançando a forma da letra do meu senhor]. A couple of cases involving the pragmatic Paralatio should be considered in the analysis of this excerpt. Paralatic pragmatics tends to occur when the translator decides to add elements, cut parts, or change the position of elements within sentences. A case occurs when Schulman not only removes the part [que fue], but also moves the English sentence [learning to write] to the end of the sentence. By his turn, Castro adds the sentence [para praticar minhas coisas] to the source version in Brazilian Portuguese.

\section{Concluding Remarks}

I think I should close this article by reaffirming that, under the theoretical and practical auspices of the double vocalization of Signifyin $(g)$ and Eshu, Manzano reaches freedom from slavery in association with liberation from poetic and literary bondage. Both the political implications of his running away from bondage and the ramifications of his escaping from artistic ignorance are the genuine racial elements of the Autobiography of a Slave, he authors. Manzano's double dislocation- both racial and literary - supports my proposal involving tradition, migration and translation in a process of call-and-response that which comprises the conversational aspects that engenders my articulation of a theory of translation based on the dialogical orientation of Signifyin $(g)$ and Eshu, within the realm of race and text: people's translation implying Manzano's interracial migration; text's translation suggesting his autobiography's intertextual migration. 
The double modality of translation illuminating Manzano's struggle for artistic freedom through assimilating his slaveholder's handwriting and white Cuban literacy in order to produce his own black oeuvre seems to enfranchise his personal and strenuous fight for freedom. Similarly, the double events of his autobiography's differentiating rendition into English and Brazilian leading to the enlargement of its readership appears to fortify its reception within the distinct worlds of these two languages and readers.

As black subject, Manzano's narrative trajectory depicts how he encompasses the individual, the communal and the political, as his life is not only a personal but also a collective agenda due to the involvement of groups of slaves, major characteristic of a minor literature. Deleuze \& Guattari (1986) suggest that, within a Minor Literature - like Black Literature $-\mathrm{a}$ text embeds in itself the individual, the collective and the political. Defining minor literature as the literary tradition that "a minority constructs in a major language", they go on to affirm that, in it "everything is political" because not only "its cramped space forces each individual intrigue to connect immediately to politics" but also because "in it everything takes on a collective value." (DELEUZE \& GUATTARI 1986: 17)

What seems to be theoretical in the French philosophers' statement becomes practical in Morrison's analysis of how a black artist joins individuality, community and politics. In favor of her position she corroborates the French thinkers' arguments saying that "there must have been a time when an artist could be genuinely representative of the tribe and in it", adding that "the re spaces and places in which a single person cold enter and behave as an individual within the context of the community. Finally, she concludes that

There must have been a time when an artist could be genuinely representative of the tribe and in it; when an artist could have a tribal or racial sensibility and an individual expression of it. There were spaces and places in which a single person could enter and behave as an individual within the context of the community. (...) The autobiographical form is classic in Black American or Afro-American literature because it provided an instance in which a writer could be representative, could say "my single solitary and individual life is like the lives of the tribe." (MORRISON 2008: 56-57)

Similarly, textual translation a black oeuvre must be regarded as encompassing also an individual, collective and political agenda from the part of the translator. By translating an individual oeuvre an individual translator deliberately decides to add the novel work to a distinct community of readers who will deal politically with the incoming text. Not only the act of rewriting (translation) but also the practice of writing an autobiography involves individuality, community and politics. Autobiography as well as novel includes both white and black literary, linguistic and cultural elements, turning an autobiography a "mulatto" text. Traditionally, an autobiography is a white and Western creation, which slaves use in order to tell both how they run away from sin (spiritual narrative) and from slavery (slave narrative). Gates (1988) evaluates the "mulatto-ness" black text, by explaining that "black writers, like critics of black literature, learn to write by reading literature, especially the canonical texts of the Western tradition", also adding that "free of the white gaze, black people their own unique vernacular structures and relished in the double play that these forms bore to white form." (GATES 1988: xxii-xxiv)

Within his black minority, Manzano can say, with Morrison, that "my single solitary and individual life is like the lives of the tribe."

\section{References}

ACHING, G. Freedom from Liberation: Slavery, Sentiment, and Literature in Cuba. BIoomington: Indiana University Press. 2015.

CHESTERMAN, A. Memes of Translation. Amsterdam: john Benjamins Publishing Company, 1997.

DELEUZE, G. \& GUATTARI, F. Kafka: Toward a Minor Literature. Trans. Dana Polan. Minneapolis: University of Minnesota Press, 1986.

DU BOIS, W. E. B. The Souls of Black Folk. In; DU BOIS, W. E. B. Writings. New York: The Library of America, 1980.

GATES, H. L., Jr. The Signifying Monkey: A Theory of African-American Literary Criticism. Oxford: Oxford University Press, 1988.

GREWAL, G. Circles of Sorrow, Lines of Struggle: The Novels of Toni Morrison. Baton Rouge: Louisiana State University Press, 1998.

GRUESSER, J. C. Confluences: Postcolonialism, African American Literary Studies, and the Black Atlantic. Athens: The University of Georgia Press, 2007.

MANZANO, J. F. Autobiografía de un Esclavo. Detroit: Wayne State University Press, 1996.

MANZANO, J. F. Autobiography of a Slave. Trad. Evelyn Picon Garfield. Detroit: Wayne State University Press, 1996.

MANZANO, J. F. A Autobiografia do Poeta-Escravo. Trad. Alex Castro. São Paulo: Hedra, 2015.

MARTINS, J. E. Tradição, Migração, Tradução: Triangulações Raciais e Linguais na Literatura Afrodescendente Traduzida no Brasil. Tese de Doutorado, UFSC. Florianópolis, 2013. 
MORRISON, T. Toni Morrison: What Moves at the Margin. Carolyn G. Denard (ed.). Jackson: University Press of Mississippi, 2008, p. 56-64.

SCHULMAN, I. A. Introduction. In: MANZANO, J. F. Autobiography of a Slave. Trad. Evelyn Picon Garfield. Detroit: Wayne State University Press, 1996, p. 05-38.

VERGÈS, F. Aimé Césaire: Nègre je Suis, Négre je Resterai. Paris : Éditions Albin Michel, 2005. 